\title{
Root carbon interaction with soil minerals is dynamic, leaving a legacy of microbially-derived
}

\section{residues}

Rachel A. Neurath ${ }^{\mathrm{a}, \mathrm{b}}$, Jennifer Pett-Ridge ${ }^{\mathrm{c}}$, Ilexis Chu-Jacoby ${ }^{\mathrm{a}}$, Donald Herman ${ }^{\mathrm{a}}$, Thea Whitman $^{\mathrm{d}}$, Peter Nico ${ }^{\mathrm{e}}$, Andrew S. Lipton ${ }^{\mathrm{f}}$, Jennifer Kyle ${ }^{\mathrm{f}}$, Malak M. Tfaily ${ }^{\mathrm{g}}$, Alison Thompson $^{\mathrm{f}}$, Mary K. Firestone ${ }^{\mathrm{a}}$

\section{Author Affiliations}

${ }^{\mathrm{a} D e p a r t m e n t}$ of Environmental Science, Policy, and Management, University of California, Berkeley; ${ }^{b}$ Biosciences Division, Lawrence Berkeley National Laboratory; ${ }^{c}$ Physical and Life Sciences Directorate, Lawrence Livermore National Laboratory; ${ }^{\mathrm{d}}$ Department of Soil Science, University of Wisconsin, Madison; ${ }^{\mathrm{e}}$ Earth Sciences Division, Lawrence Berkeley National Laboratory; ${ }^{\mathrm{f}}$ Environmental Molecular Sciences Laboratory, Pacific Northwest National Laboratory; ${ }^{\mathrm{g}}$ Department of Environmental Science, University of Arizona

\section{Keywords}

Rhizosphere, soil organic matter, grassland, ${ }^{13} \mathrm{C}-\mathrm{NMR}$, FTICR-MS, lipidomics, microbemineral interactions 


\section{Synopsis}

This study explores the interaction of rhizosphere carbon, minerals, and microbial influence on the fate of soil carbon.

\section{TOC}

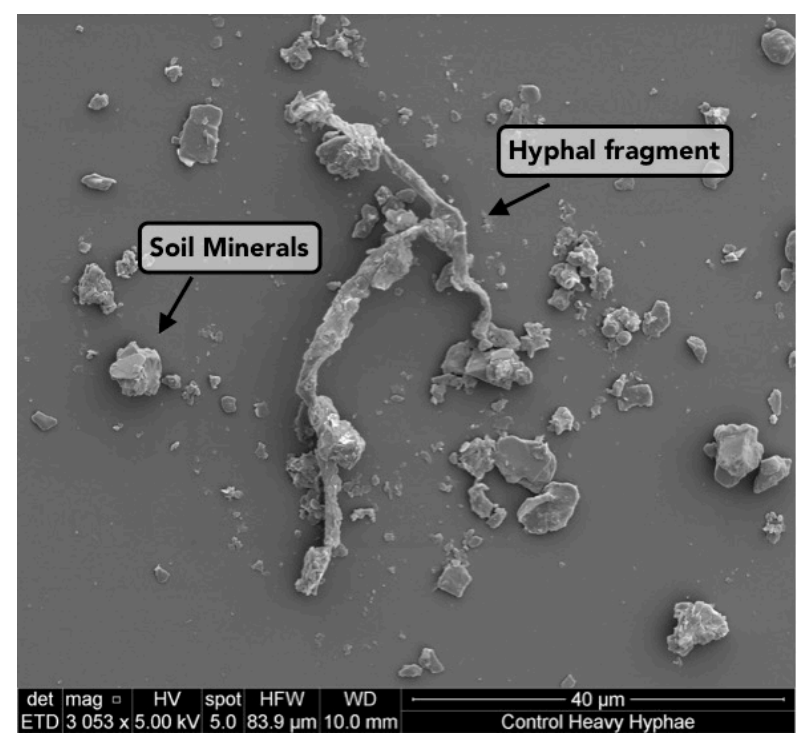




\section{ABSTRACT}

Minerals preserve the oldest most persistent soil carbon, and mineral characteristics appear to play a critical role in the formation of soil organic matter (SOM) associations. To test the hypothesis that carbon source and soil microorganisms also influence mineralSOM associations, we incubated permeable minerals bags in soil microcosms with and without plants, in a ${ }^{13} \mathrm{CO}_{2}$ labeling chamber. Mineral bags contained quartz, ferrihydrite, kaolinite, or native soil minerals isolated via density separation. Using ${ }^{13} \mathrm{C}-\mathrm{NMR}$, FTICRMS, and lipidomics, we traced plant-derived carbon onto minerals harvested from microcosms at three plant growth stages, characterizing total carbon, ${ }^{13} \mathrm{C}$ enrichment, and SOM chemistry. While $\mathrm{C}$ accumulation was rapid and mineral-dependent, the accumulated amount was not significantly affected by the presence of plant roots. However, the rhizosphere did shape the chemistry of mineral-associated SOM. Minerals incubated in the rhizosphere were associated with a more diverse array of compounds with different $\mathrm{C}$ functional groups (carbonyl, aromatics, carbohydrates, lipids) than minerals incubated in a bulk soil control. These diverse rhizosphere-derived compounds may represent a "transient fraction" of mineral SOM, rapidly exchanging with mineral surfaces. Our results also suggest that many of the lipids which persist on minerals are microbially-derived with a large fraction of fungal lipids. 


\section{INTRODUCTION}

Plant roots are the primary mediators of carbon $(\mathrm{C})$ transfer into soil ${ }^{1-3}$, allocating $\mathrm{C}$ captured from the atmosphere to the soil system ${ }^{4}$. Root $\mathrm{C}$ is then transformed within the soil, where it may be respired back to the atmosphere or stored as soil organic matter $(\mathrm{SOM})^{5}$. Association with soil minerals offers a degree of protection for $\mathrm{SOM}^{6-11}$, however the residence time of this SOM varies widely ${ }^{12}$, due to a complex interplay of soil and microbial processes ${ }^{13-14}$. Why some mineral-associated $\mathrm{C}$ persists and some does not is a central question in the field of soil $\mathrm{C}$ dynamics ${ }^{15}$, with important implications for soil health, fertility, and microbial community ecology ${ }^{16-19}$.

In grassland ecosystems, most surface soils are periodically or continually in the zone of root influence, or rhizosphere ${ }^{20}$. As plant roots transfer organic compounds to the soil, the fate of this $\mathrm{C}$ is determined by (i) microbial community composition and activity ${ }^{19,21-}$ ${ }^{23}$, (ii) the chemical form of the $\mathrm{C}^{24}$, (iii) where within the soil physical environment it is located ${ }^{25}$, and (iv) soil mineral sorption capacity ${ }^{22,26}$. More than just a $\mathrm{C}$ source, growing roots physically and chemically alter the soil environment ${ }^{27-29}$, with significant implications for the fate of soil C.

The rhizosphere is the nexus of plant-soil-microbe interactions ${ }^{30-31}$. While plant growth provides a $\mathrm{C}$ source and stimulates microbial activity ${ }^{32-33}$, root production of organic acids, such as oxalic acid, can release organo-metal complexes from mineral surfaces ${ }^{29}$. Thus, roots influence both $\mathrm{C}$ association with minerals and also $\mathrm{C}$ loss. Microorganisms also interact with minerals, associating with mineral surfaces for protection from 
predation and desiccation, access to nutrients and energy sources, and as a platform for biofilm formation ${ }^{34-40}$. Thus, it is now widely recognized that microbial necromass is a key part of mineral-associated SOM ${ }^{26,41-43}$. We hypothesize that the synergy of growing plant roots and rhizosphere microorganisms results in altered composition and quantity of mineral-associated SOM, an influence that takes place in the context of well-documented effects of mineral type on mineral-associated SOM quantity ${ }^{6}$, composition ${ }^{44}$, and persistence $^{8,24,45-47}$.

Here, we considered how biogeochemical differences between the rhizosphere and bulk soil might impact $\mathrm{C}$ persistence on minerals. As a zone of active $\mathrm{C}$ release and microbial activity, the rhizosphere is also characterized by both a lower degree of spatial heterogeneity and reduced microbial diversity ${ }^{23}$. Recent work by Lehmann et al. ${ }^{14}$ suggests that functional complexity predicts soil carbon persistence. However, it is currently unknown whether the rhizosphere has higher or lower molecular functional diversity than bulk soil, but it is clearly more dynamic, with high diurnal ${ }^{48-49}$ and seasonal ${ }^{33,50}$ temporal variability. Given this framework, we predict that rhizosphere SOM may turn over more rapidly than in the bulk soil.

In soil microcosms with living plants (Avena barbata), we incubated four mineral types in a ${ }^{13} \mathrm{CO}_{2}$ growth chamber, allowing us to trace the fate of ${ }^{13} \mathrm{C}$-enriched plant-derived $\mathrm{C}$. Our objectives were (1) to determine the influence of active roots on SOM association with mineral surfaces, (2) to determine the influence of mineral type on the quantity and composition of mineral-associated SOM, and (3) to explore the role of microorganisms in 
transformation of mineral-associated SOM. We found that while mineral type dictated the total quantity of mineral-associated SOM, the combined effect of mineral type and exposure to root growth defined the chemical composition of mineral-associated SOM. Rhizosphere SOM was compositionally more diverse than the bulk soil, but also appeared more transient, with higher turnover.

\section{MATERIALS AND METHODS}

\subsection{Experimental Design}

The study soil and plant type used in our soil microcosms were chosen to represent a typical Mediterranean-climate grassland ecosystem, with a fertile Alfisol soil and the naturalized slender wild oat grass Avena barbata. Both the soil and A. barbata seeds used in the soil microcosms were collected from Little Buck Field $\left(38.992938^{\circ} \mathrm{N}\right.$, $\left.123.067714^{\circ} \mathrm{W}\right)$, a managed pasture that is grazed by sheep, at the Hopland Research and Extension Center (HREC), Hopland, CA, in March, 2014, just before the start of the summer dry season. This field site is well characterized ${ }^{51}$, and the microbial community has been studied extensively ${ }^{23,32-33,52-56}$. The soil, a fine-loamy, mixed, active, mesic Typic Haploxeralf ${ }^{51}$, was sieved to $<2 \mathrm{~mm}$ in the field, dried to 1.1 volumetric water content (VWC), and stored at $4^{\circ} \mathrm{C}$. Field soil had a field bulk density of $1.2 \mathrm{~g}-\mathrm{cm}^{-3}$, a $\mathrm{pH}$

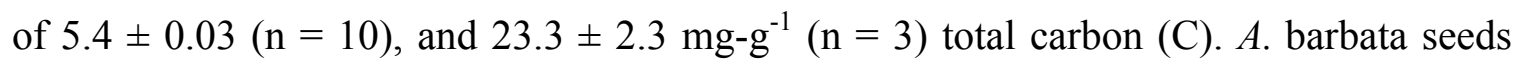
were collected in the field, dried, and scarified before germination.

Microcosms $(2.9 \times 11.5 \times 25.3 \mathrm{~cm})(\mathrm{n}=30)$ were filled with soil to field bulk density $(1.2$ g-cm ${ }^{-3}$ ) (SI Figure 1), with 5 microcosms per treatment (bulk and rhizosphere) for each 
time point (1, 2, and 2.5 months). Before filling the microcosms, perforated tubing was inserted along one face of the microcosm (SI Figure 1a) to allow for even watering; in 12 microcosms, a volumetric water content (VWC) sensor (Decagon, EC5) was buried at approximately $10 \mathrm{~cm}$ depth and VWC was maintained at 14\%, the average for Hopland soil during the growing season. Along the opposite face of the microcosm, a $2 \mathrm{~mm}$ width sidecar panel was inserted to keep that area free of soil and roots. We had two treatment types: (1) a rhizosphere treatment, with actively growing $A$. barbata planted in the soil microcosm, and (2) a bulk soil treatment, which was left unplanted. For the rhizosphere treatment, four germinated A. barbata seedlings were planted in each microcosm, simulating field density (SI Figure 1b). Microcosms were then tilted at $45^{\circ}$, with the sidecar facing downward, for one month (SI Figure 1c-d). Due to geotropism, roots grew along the sidecar panel face (SI Figure 1e).

After one month of plant growth, microcosms were opened along the sidecar face and the sidecar panel was removed, leaving a $2 \mathrm{~mm}$ gap. Nylon mesh bags $(18 \mu \mathrm{m}$ mesh, $5 \mathrm{x} 5 \mathrm{x}$ $0.2 \mathrm{~cm}$ dimensions) filled to field bulk density with one of four mineral types were placed in this gap, directly adjacent to the actively growing $A$. barbata roots, and then packed with soil. These minerals included: quartz sand ("Quartz"), ferrihydrite-coated quartz sand ("Ferrihydrite"), 50:50 by mass mixture kaolinite and quartz sand ("Kaolinite"), or the heavy density fraction (>1.75 g- $\left.\mathrm{cm}^{-1}\right)$ ("Native Minerals") of Hopland soil (Figure 1, SI Figure 1f). Mineral preparation is described in the SI Methods. The specimen minerals added reflect the dominant mineral types present at our field site (determined by XRD, see SI Methods) and were selected to represent a range of surface area and 
reactivity, from quartz with low surface area and low reactivity to kaolinite with high surface area and moderate surface reactivity to ferrihydrite, an amorphous iron oxyhydroxide, with moderate surface area and high surface reactivity (SI Table 1). The Native Minerals were density fractionated from field soil. We mixed kaolinite with quartz to prevent formation of large kaolinite aggregates and allow more permeability than pure kaolinite alone.

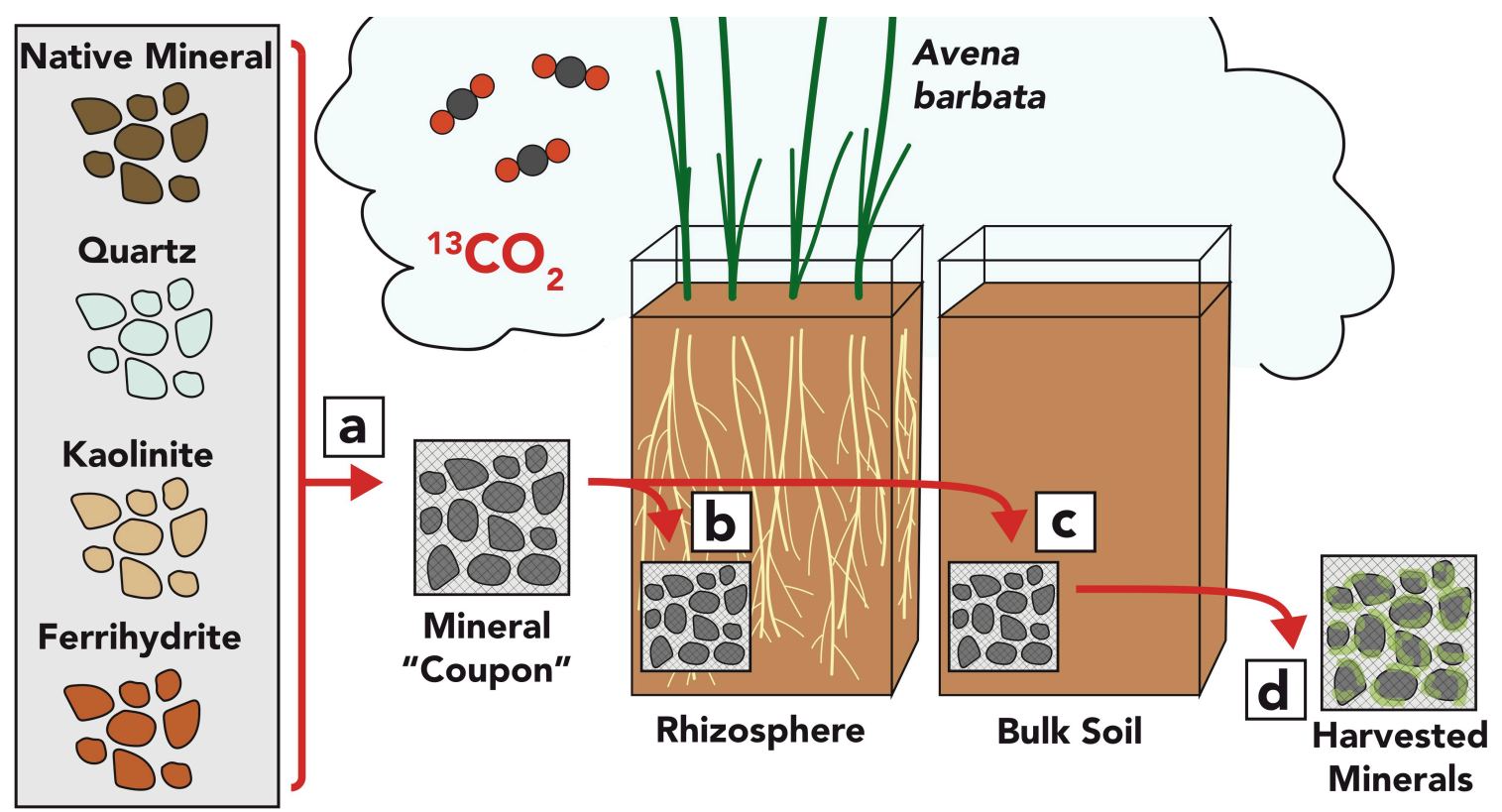

Figure 1. Experimental design for a rhizosphere mineral incubation in a Mediterranean-climate grassland soil from Hopland CA. Four mineral types, (1) "Native Minerals" (density fractionated from the soil), (2) "Quartz" (quartz sand), (3) "Kaolinite" (50:50 mix by volume of kaolinite and quartz sand), and (4) "Ferrihydrite" (ferrihydrite coated quartz sand), were placed in nylon mesh bags and placed in soil microcosms with growing Avena barbata plants (rhizosphere treatment) or no plants (bulk treatment). All microcosms were incubated in a 99 atom\% ${ }^{13} \mathrm{CO}_{2}$ labeling chamber. Microcosms were destructively harvested and mineral bags collected after 1, 2, and 2.5 months of incubation. 
Mineral bags were harvested after 1, 2, and 2.5 months incubation, at which point $A$. barbata had reached senescence (Figure 1, SI Figure 1g). At harvest, both minerals and bulk soil were weighed, dried $\left(65^{\circ} \mathrm{C}\right)$, and weighed again to obtain soil moisture content. The dried minerals and soil were stored at $4^{\circ} \mathrm{C}$ until analysis.

\subsection{Total C and Isotope Ratio Mass Spectrometry}

To measure total $\mathrm{C}$ accumulation on mineral surfaces, in bulk soil, and in root tissues, we used Elemental Analysis (EA) coupled to an IsoPrime 100 Isotope Ratio Mass Spectrometer (IRMS) (Isoprime Ltd, Cheadle Hulme, UK) to simultaneously measure total $\mathrm{C}$ and ${ }^{13} \mathrm{C}$ enrichment in dried and ground minerals, bulk soil and roots. Peach leaf standards (NIST SRM 1547) were run to ensure accuracy and technical replicates for precision.

\subsection{Scanning Electron Microscopy and BET Surface Area}

Minerals were imaged with Scanning Transmission Electron Microscopy (SEM) at Lawrence Livermore National Laboratory (FEI, Inspect F) before and after incubation in the soil microcosms. Mineral samples were mounted and gold-coated and then images were acquired at $5 \mathrm{kV}$ energy. The surface area of the minerals was determined before and after incubation by Brunauer-Emmett-Teller (BET) analysis with $\mathrm{N}_{2}$ gas at Lawrence Berkeley National Laboratory. 


\section{4. ${ }^{13}$ C-Nuclear Magnetic Resonance Mass Spectrometry}

Major chemical classes of mineral-associated organic matter were identified by ${ }^{13} \mathrm{C}$ Nuclear Magnetic Resonance Mass Spectrometry. Finely ground samples were packed in a $5 \mathrm{~mm}$ optical density ceramic rotor and analyzed by $500 \mathrm{MHz}$ solid-state ${ }^{13} \mathrm{C}-\mathrm{NMR}$ (Oxford) at the Environmental Molecular Sciences Laboratory (EMSL) at the Pacific Northwest National Laboratory (PNNL). Standards of potassium bromide and adamantine were run at 5,000 Hz. A soil standard, "Pahokee Peat" (IHSS, Standard Sample), collected from Florida and sieved to $<53 \mu \mathrm{m}$, was also analyzed. The low $\mathrm{C}$ concentrations in our samples required long ${ }^{13} \mathrm{C}-\mathrm{NMR}$ experiments, thus we ran pooled samples $(n=3)$ for each mineral type rather than replicates. Due to the interference of iron in the ferrihydrite sample and a low signal-to-noise ratio in the quartz sample, we were unable to obtain suitable ${ }^{13} \mathrm{C}-\mathrm{NMR}$ spectra from those mineral types (SI Figure 4).

\subsection{Fourier Transform Ion Cyclotron Resonance Mass Spectrometry}

FTICR-MS and lipidomics (see section 3.6. below) analysis of mineral samples extracted with water (FTICR-MS) and then chloroform/methanol (lipidomics ${ }^{57}$ ) was conducted at EMSL. Analyses were conducted on dried mineral samples from the 2-month time point. We ran 3 biological replicates of each sample.

FTICR-MS analysis is discussed in detail in SI Methods. Briefly, samples were dried and extracted with $\mathrm{MeOH}$ for chemical characterization on a $12 \mathrm{~T}$ Bruker SolariX FTICR mass spectrometry, as previously described in Tfaily et al. $(2017,2018)^{58-59}$. Putative chemical formulas were assigned using Formularity software ${ }^{60}$. Compounds were plotted 
on van Krevelen diagrams based on their molar $\mathrm{H}: \mathrm{C}$ ratios ( $y$-axis) and molar O:C ratios $(x \text {-axis })^{61}$

\subsection{Lipidomics}

Total lipid extracts were analyzed in both positive and negative modes, and lipids were fragmented using higher-energy collision dissociation and collision-induced dissociation. Confident lipid identifications were made using LIQUID (LIpid QUantitation and IDentification) ${ }^{62}$. Aligned features were manually verified and peak apex intensity values were exported for statistical analysis. Identified lipids were selected by manually evaluating the MS/MS spectra for diagnostic and corresponding acyl chain fragment ions. In addition, the precursor isotopic profile, extracted ion chromatogram, and mass measurement error along with the elution time were evaluated. All LC-MS/MS runs were aligned and gap-filled using the identified lipid name, observed $\mathrm{m} / \mathrm{z}$, and the retention time using MZmine $2^{63}$. Each ionization type was aligned and gap-filled separately. Aligned features were manually verified and peak apex intensity values were exported for statistical analysis.

\subsection{Sequential Extraction}

To characterize the bonds between mineral surfaces and associated SOM, we performed a series of sequential extractions, adapted from Heckman et al. ${ }^{64}$ : (1) a water extraction was used to remove weakly mineral-associated soluble SOM (e.g. Van der Waals, dipoledipole forces); (2) $0.1 \mathrm{M}$ tetra-sodium pyrophosphate extraction ${ }^{65}$ for organic-metal complexes and base soluble $\mathrm{C}$; and (3) $0.25 \mathrm{M}$ hydroxylamine ${ }^{65-66}$ for non-crystalline 
and poorly crystalline iron and aluminum and associated C. We conducted sequential extractions on 3 biological replicates of each sample. For the sequential extractions, 40 $\mathrm{mL}$ extraction reagent was added to $3 \mathrm{~g}$ mineral sample, vortexed, shaken overnight, centrifuged and the supernatant decanted and passed through a $0.2 \mu \mathrm{m}$ Whatman GX/D syringe filter. The residual minerals were rinsed with sterilized MilliQ water three times. The filtered supernatant was analyzed by ICP-MS (Perkin-Elmer Elan DRC II). The residual minerals were dried and analyzed for total $\mathrm{C}$ and ${ }^{13} \mathrm{C}$ by EA and IRMS.

\subsection{Mixing Model}

To calculate the relative contribution of total $\mathrm{C}$ on mineral surfaces from the actively growing $A$. barbata plant, we used a mixing model (Eq. 1) ${ }^{67}$. In this model, the two pools of $\mathrm{C}$ were the $A$. barbata root and the bulk soil:

$$
E_{M}=E_{R} \cdot f_{R}+E_{B} \cdot f_{B}
$$

Eq. 1

Where $\boldsymbol{E}_{\boldsymbol{M}}$ is the atom $\%$ enrichment of the mineral, $\boldsymbol{E}_{\boldsymbol{R}}$ is the atom $\%$ enrichment derived from the A. barbata root, $\boldsymbol{f}_{\boldsymbol{R}}$ is the fraction of $\mathrm{C}$ from the root, $\boldsymbol{E}_{\boldsymbol{B}}$ is the atom $\%$ enrichment derived from the bulk soil, and $\boldsymbol{f}_{\boldsymbol{B}}$ is the fraction of $\mathrm{C}$ from the bulk soil. In our equation, $f_{R}+f_{B}=1$.

Bulk soil had a natural abundance ${ }^{13} \mathrm{C}$ of $1.074 \pm 0.001$ atom $\%$. Plant roots were pooled, ground, and analyzed by IRMS to calculate an average enrichment of $7.191 \pm 0.398 \mathrm{SE}$ atom $\%{ }^{13} \mathrm{C}$. 


\subsection{Statistics}

Carbon concentrations and ${ }^{13} \mathrm{C}$ ratios are reported with standard error $(n=5)$. We used a partially-nested mixed effects model according to Doncaster and Davey ${ }^{68}$ to analyze the total $\mathrm{C}$ and IRMS results. We conducted analysis of variance (ANOVA) on these data, using the nlme package ${ }^{69}$ in R v.3.5.1 (R Core Team, 2018) on log-transformed data to maintain assumptions of normality. To conduct pairwise comparisons, we used the emmeans package ${ }^{70}$ in R. For FTICR-MS data, we performed non-metric multidimensional scaling (NMDS) analysis using presence/absence data and Jaccard distances to determine group differences, using the package ftmsRanalysis in $\mathrm{R}^{71}$. To determine whether the differences illustrated in the NMDS plot were significant, we ran a permutational multivariate ANOVA (PERMANOVA) analysis in $\mathrm{R}$ using the adonis function in the vegan package ${ }^{72}$. We performed principal coordinate analysis (PCoA) with a Bray-Curtis dissimilarity matrix on the lipidomic data to determine sub-class

differences in $\mathrm{R}$ using the vegan package ${ }^{72}$. To determine whether the differences in the PCoA plot were significant, we ran a PERMANOVA analysis in $\mathrm{R}$ using the adonis function in the vegan package ${ }^{72}$.

\section{RESULTS AND DISCUSSION}

\subsection{Mineral type controls total $\mathrm{C}$ accumulation on minerals}

All specimen minerals (Quartz, Kaolinite, and Ferrihydrite) had no detectable C prior to incubation. Carbon accumulated on all specimen mineral types in both the rhizosphere and bulk soil treatments (Figure 2 a, SI Figure 3) and in SEM images, we observed visual evidence of $\mathrm{C}$ accumulation on the mineral surfaces (SI Figure 2). This C 
accumulation was rapid; the majority of $\mathrm{C}$ association with minerals occurred in the first month. While total $\mathrm{C}$ associated with kaolinite and quartz did not increase after 1 month of incubation, the enrichment of the $\mathrm{C}(\mathrm{atm} \%)$ associated with the minerals continued to increase until 2 to 2.5 months (Figure $2 \mathrm{a}$ and b). Total $\mathrm{C}$ concentration varied significantly by mineral type $(\mathrm{p}<0.0001)$. When expressed as total $\mathrm{C}$ per gram mineral, the most $\mathrm{C}$ was associated with Ferrihydrite $\left(1.3 \pm 0.3 \mathrm{mg} \mathrm{C}-\mathrm{g}^{-1}\right.$ for rhizosphere at 2.5 months) (Figure 2a). However, when normalized to BET-measured surface area (SI Table 1), Quartz had the highest concentration of total C per square meter mineral surface (11.4 $\pm 1.6 \mathrm{mg} \mathrm{C}-\mathrm{m}^{-2}$ for rhizosphere at 2.5 months) (SI Figures 3-4). This near reversal in trend reveals an important distinction in how total $\mathrm{C}$ measurements are presented. Here, we focus on total $\mathrm{C}$ per gram mineral because this better reflects how soil $\mathrm{C}$ stocks are expressed in most ecosystem assessments and model representation. We did not find a significant plant vs. bulk treatment effect for total $\mathrm{C}$ across all minerals $(p=0.250)($ SI Figure 4).

Carbon concentrations on specimen minerals were more than an order of magnitude lower than on the Native Minerals, with an average total $\mathrm{C}$ of $0.6 \pm 0.1 \mathrm{mg} \mathrm{C}-\mathrm{g}^{-1}$ for the specimen minerals in the rhizosphere versus $17.0 \pm 1.0 \mathrm{mg} \mathrm{C}-\mathrm{g}^{-1}$ for the Native Minerals (SI Figure 4). For our specimen minerals (Quartz, Ferrihydrite, and Kaolinite), we assume that at the end of the growing season we are still far from "carbon saturation" 73 ${ }^{75}$. Considering that the Native Minerals have likely resided in the soil for thousands of years or more ${ }^{76}$, the relatively low specimen mineral C concentrations suggest that while C may accumulate rapidly on fresh mineral surfaces, the rate slows down over time. 
Indeed, in the short 2.5 months of our study, we observed a linear rate of $\mathrm{C}$ accumulation on Ferrihydrite, whereas Quartz and Kaolinite minerals had rapid initial C accumulation followed by a leveling off (Figure 2a). The Native Minerals did not accumulate a significant amount of additional total $\mathrm{C}$ in either rhizosphere or bulk soil compared with their initial total $\mathrm{C}$ concentration $(\mathrm{p}=0.101)$. Our study observes a single plant growing season, and therefore offers a critical snapshot of $\mathrm{C}$ accumulation and exchange on a mineral surface.

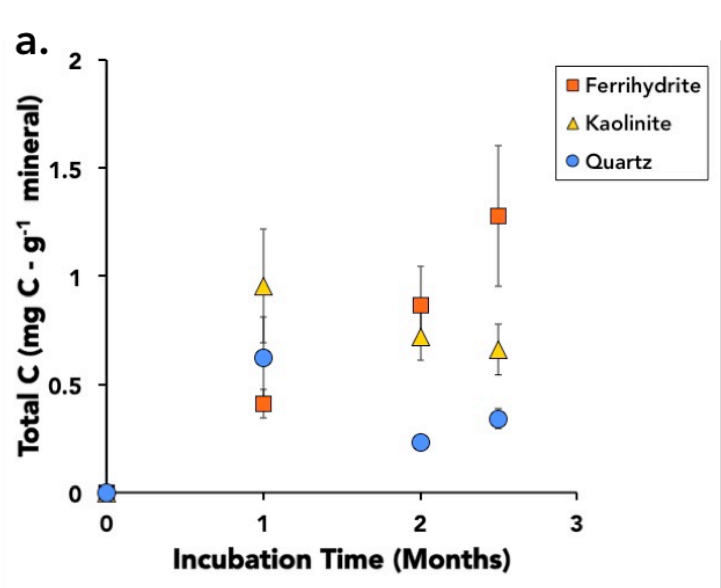

b.

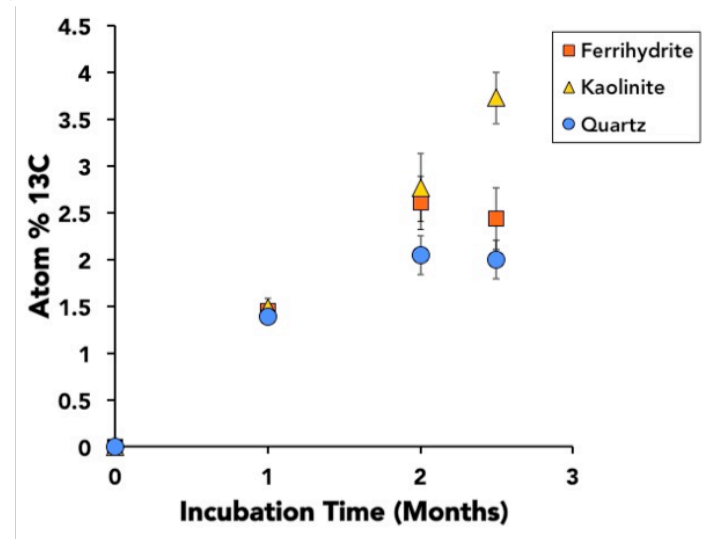

Figure 2. Total carbon (C) (a) and atom $\%{ }^{13} \mathrm{C}$ (b) of pure minerals: Ferrihydrite, Kaolinite, and Quartz, incubated in the rhizosphere of Avena barbata plants growing in a ${ }^{13} \mathrm{CO}_{2}$ atmosphere. Panel (a) shows mineral total C accumulation over time. Panel (b) shows atom $\%{ }^{13} \mathrm{C}$, reflecting mineralassociated $\mathrm{C}$ derived from the $\boldsymbol{A}$. barbata roots. Error bars are standard error $(\mathrm{N}=5)$.

Rhizosphere-derived C contributed a significant portion of the $\mathrm{C}$ on mineral surfaces (Table 1) based on a ${ }^{13} \mathrm{C}$ mixing model (Eq. 1). The percent rhizosphere-derived $\mathrm{C}$ significantly increased for all specimen minerals from 1 to 2 months $(\mathrm{p}<0.001)$, and continued to increase significantly from 2 to 2.5 months for Kaolinite (Figure $\mathbf{2 b}$ ). 
However, the rhizosphere treatment had no significant effect on the total amount of mineral-associated C. Thus, over the timescale of a single plant growing season, while there was evidence of plant-derived $\mathrm{C}$ on the minerals based on ${ }^{13} \mathrm{C}$ tracing, the addition of root $\mathrm{C}$ to the microcosms did not result in a net increase in total mineral $\mathrm{C}$, as compared to minerals that were incubated in bulk soil.

Table 1. Percent C from A. barbata Rhizosphere

\begin{tabular}{|c|c|c|}
\hline Time & Mineral & \% Rhizosphere C \\
\hline \multirow[t]{3}{*}{1 month } & Ferrihydrite & $4.89 \pm 5.5$ \\
\hline & Kaolinite & $5.40 \pm 4.6$ \\
\hline & Quartz & $1.44 \pm 3.4$ \\
\hline \multirow[t]{4}{*}{2 month } & Ferrihydrite & $24.0 \pm 5.5$ \\
\hline & Kaolinite & $26.7 \pm 4.6$ \\
\hline & Quartz & $14.7 \pm 3.4$ \\
\hline & Native Mineral & $6.24 \pm 0.40$ \\
\hline \multirow[t]{3}{*}{2.5 month } & Ferrihydrite & $21.2 \pm 5.5$ \\
\hline & Kaolinite & $42.6 \pm 4.6$ \\
\hline & Quartz & $13.9 \pm 3.4$ \\
\hline
\end{tabular}

A possible explanation for the absence of a rhizosphere effect on total $\mathrm{C}$ is that, while the total $\mathrm{C}$ stock remained the same, the fluxes of $\mathrm{C}$ were different. To illustrate, the stock of mineral associated $\mathrm{C}$ at time $t,\left(\boldsymbol{M}_{\boldsymbol{t}}\right)$, is equal to the stock of mineral associated $\mathrm{C}$ at time 
zero, $\left(\boldsymbol{M}_{0}\right)$, plus the amount sorbed during time interval $\Delta t,\left(\Delta t \cdot \boldsymbol{S}_{t}\right)$, minus the amount desorbed during time interval $\Delta t,\left(\Delta t \cdot D_{t}\right)$ :

$$
M_{t}=M_{0}+\Delta t\left(S_{t}-D_{t}\right)
$$

where:

$$
\begin{aligned}
& M_{t}=\text { stock of mineral } C \text { at time interval } t \\
& M_{0}=\text { stock of mineral } C \text { at time } 0 \\
& \Delta t \cdot S_{t}=\text { sorption flux } S_{t} \text { at time interval } \Delta t \\
& \text { where: } \\
& S_{t}=S_{t 1}+S_{t 2}+\ldots+S_{t x} \\
& S_{t x}=\text { sorption of } C \text { from compound } x \\
& \Delta t \cdot D_{t}=\text { desorption flux } D_{t} \text { at time interval } \Delta t \\
& \text { where: } \\
& D_{t}=D_{t 1}+D_{t 2}+\ldots+D_{t x} \\
& D_{t x}=\text { desorption of } C \text { from compound } x
\end{aligned}
$$

In our proposed equation, a modification of the classic mass-balance expression for net adsorption (See Eq. $8.8^{77}$ ), $\Delta t \cdot \boldsymbol{S}_{t}$, is the aggregate sorption for each $\mathrm{C}$ compound that associates with the mineral, $\boldsymbol{S}_{t x}$. Then $\Delta t \cdot \boldsymbol{D}_{t}$, is the aggregate desorption for each $\mathrm{C}$ compound that associates with the mineral, $\boldsymbol{D}_{t x}$. The $\boldsymbol{S}_{t x}$ of a particular compound - for example, lipids - may not be the same as the $\boldsymbol{D}_{t x}$ for that same compound; indeed, we believe they often are different. Thus, it is not only the rate at which compounds are 
sorbed and desorbed from the mineral, but also the composition of those compounds that matters, as we discuss further in section 3.4.

We hypothesize that in the rhizosphere, there is a larger supply of $\mathrm{C}^{20,23}$, but there is also a faster turnover rate of mineral-associated $\mathrm{C}$, which is consistent with Lehmann et al.'s ${ }^{14}$ functional diversity framework, and the substantial literature on rhizosphere priming ${ }^{78}$ as well as recent work showing that more living microbes - as we would expect in the rhizosphere - can lead to less $\mathrm{C}$ retention ${ }^{79}$. For example, Kaolinite did not accumulate more total $\mathrm{C}$ after 1 month, and Quartz had a slight decline in total C (Figure 2a), while the atom $\%{ }^{13} \mathrm{C}$ of that $\mathrm{C}$ continued to increase (Figure $2 \mathbf{b}$ ). We observed the same pattern when we calculated the percent contribution of ${ }^{13} \mathrm{C}$ derived from the Avena barbata rhizosphere with our mixing model (Eq. 1). These results imply that there is active exchange of non-root derived $\mathrm{C}$ with new root derived $\mathrm{C}$ while maintaining the same total C concentration associated with the mineral. The chemistry of SOM associated with minerals incubated in the rhizosphere provides further evidence in support of our hypothesis, as discussed in section 4.2.

However, we cannot discount the possibility of a simpler explanation. If the rate of sorption of $\mathrm{C}$ to the mineral surface is not limited by the availability of $\mathrm{C}$ in the bulk soil, than it is possible that the rate of $\mathrm{C}$ exchange is the same as that in the rhizosphere. Further work is needed to test our hypothesis that mineral-associated $\mathrm{C}$ turnover is, indeed, faster in the rhizosphere than in bulk soil. 


\subsection{Mineral-associated SOM chemistry depends on mineral type and treatment}

We used ${ }^{13} \mathrm{C}-\mathrm{NMR}$ to assess the molecular composition of mineral associated $\mathrm{C}$. In contrast to the mineral total $\mathrm{C}$ accumulation, in the ${ }^{13} \mathrm{C}-\mathrm{NMR}$ spectra we observed a marked difference between rhizosphere and bulk soil treatments (Figure 3). While the ${ }^{13} \mathrm{C}-\mathrm{NMR}$ spectra for minerals in the rhizosphere show peaks across major organic carbon functional group (carbonyls, aromatics, carbohydrates, and lipids), the bulk soil treatment is defined by a single prominent lipid/aliphatic peak. Thus, while the rhizosphere treatment is characterized by a diverse array of carbon functional groups, the bulk soil treatment is distinct in its homogeneity. This suggests that the rhizosphere contributed a higher molecular diversity of organic C compounds than bulk soil.

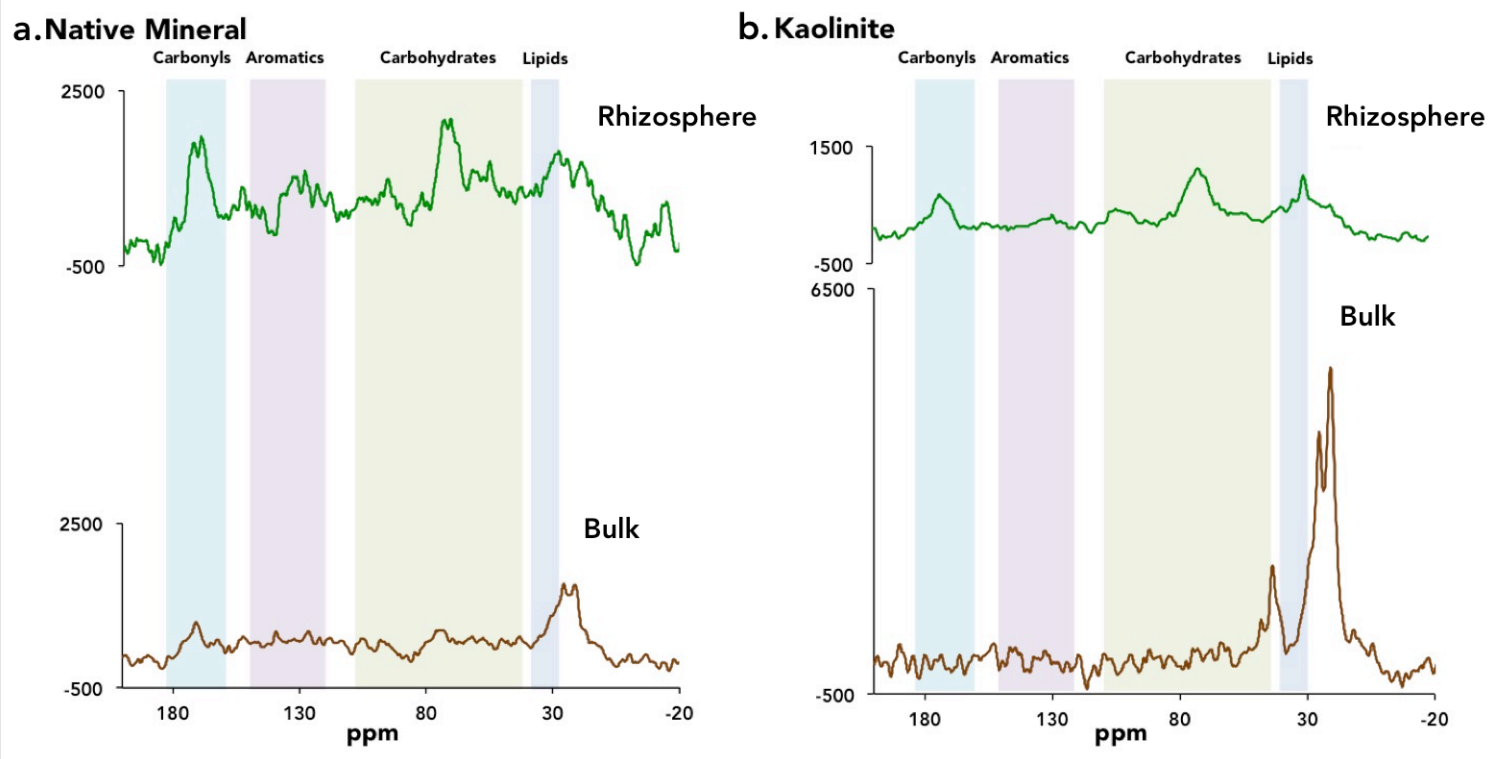

Figure 3. Solid-state ${ }^{13}$ C-NMR spectra for Native Minerals (separated via density fractionation) (a) and Kaolinite minerals (b), incubated in soil microcosms with rhizosphere and bulk soil treatments. Each spectra represents analysis of 3 pooled biological replicates. Peaks are clustered into broad organic carbon functional group categories: carbonyls, aromatics, carbohydrates, and lipids. 
The striking contrast in organic $\mathrm{C}$ chemistry associated with the Native Minerals in the rhizosphere treatment versus those in the bulk soil suggests that the rhizosphere habitat dramatically altered the chemistry of mineral-associated SOM, even though only $6 \%$ of the $\mathrm{C}$ on the Native Minerals was directly derived from plant roots (based on our mixing model; Table 1). In the rhizosphere, roots are known to exude a wide array of small molecular weight compounds ${ }^{50}$, promoting the growth of a phylogenetically distinct ${ }^{80}$, and potentially chemically distinct microbial community. The ${ }^{13} \mathrm{C}-\mathrm{NMR}$ chemical signature of the rhizosphere Native Minerals suggests mineral-associated $\mathrm{C}$ is rapidly exchanging with a complex $\mathrm{C}$ pool comprised of rhizodeposits and associated organisms. By contrast, the carbon sources available in the bulk soil - which might include $\mathrm{C}$ from microbial and soil fauna products (e.g. extracellular polymeric substances (EPS) and microbial necromass) and dissolved organic C (DOC) - may be preferentially retained on the mineral surface such that only lipid/aliphatic residues remain. Since the chemistry of mineral-associated SOM is thought to be an important predictor of C persistence ${ }^{6-7,45-46}$, our results suggest that the relative proportion of minerals under the influence of actively growing roots versus those in a bulk soil setting may determine the overall molecular complexity of mineral-bound SOM. In addition, our finding that the Native Minerals acquired a unique rhizosphere chemical signature in a single plant growing season provides another line of support for our hypothesis that in the rhizosphere, mineralassociated $\mathrm{C}$ turns over faster.

We used FTICR-MS to measure the molecular composition of soluble SOM. These water-extractable compounds can be considered a "transient fraction" of mineral 
associated SOM: loosely associated compounds that are likely easily exchanged with soil pore water. Samples analyzed by FTICR-MS were significantly different by mineral type $(\mathrm{p}<0.001)$, but not treatment (rhizosphere versus bulk) $(\mathrm{p}>0.115)$ (SI Figure 8). The compounds detected by FTICR-MS (SI Figure 9) differ compositionally from those detected in the ${ }^{13} \mathrm{C}-\mathrm{NMR}$ (which represents the entire mineral-associated pool), suggesting that the transient, water-extractable fraction may represented only a subset of the total range of compounds present on the minerals. The extractability of these compounds appeared to depend on mineral type.

Given the apparent importance of mineral associated lipids observed in our ${ }^{13} \mathrm{C}$-NMR results, as well as in the literature ${ }^{81}$, we determined the fingerprint of lipid identity and distribution on our samples. We identified a total of 113 unique lipids. The distribution of unique classes of lipids was significantly different by mineral type $(p<0.001)$ (SI Figure 7). The interaction of mineral type and rhizosphere versus bulk soil treatment was also significant $(p<0.025)$ with a moderate effect of rhizosphere versus bulk soil treatment $(\mathrm{p}>0.063)$.

While differences in ionization potential prevent us from comparing between lipid categories, within a class we compared between mineral types and treatments (Figure 4). The Native Minerals had the highest lipid intensities for the majority of lipids observed in both rhizosphere and bulk soil treatments. Overall, Kaolinite had the second highest lipid intensities, with some triacylglyceride (TG) intensities higher than those on the Native Minerals. Overall, intensities of lipid classes associated with the specimen minerals types 
(Ferrihydrite, Kaolinite, and Quartz) were higher in the bulk soil treatment than the rhizosphere. This was particularly true of Ferrihydrite.

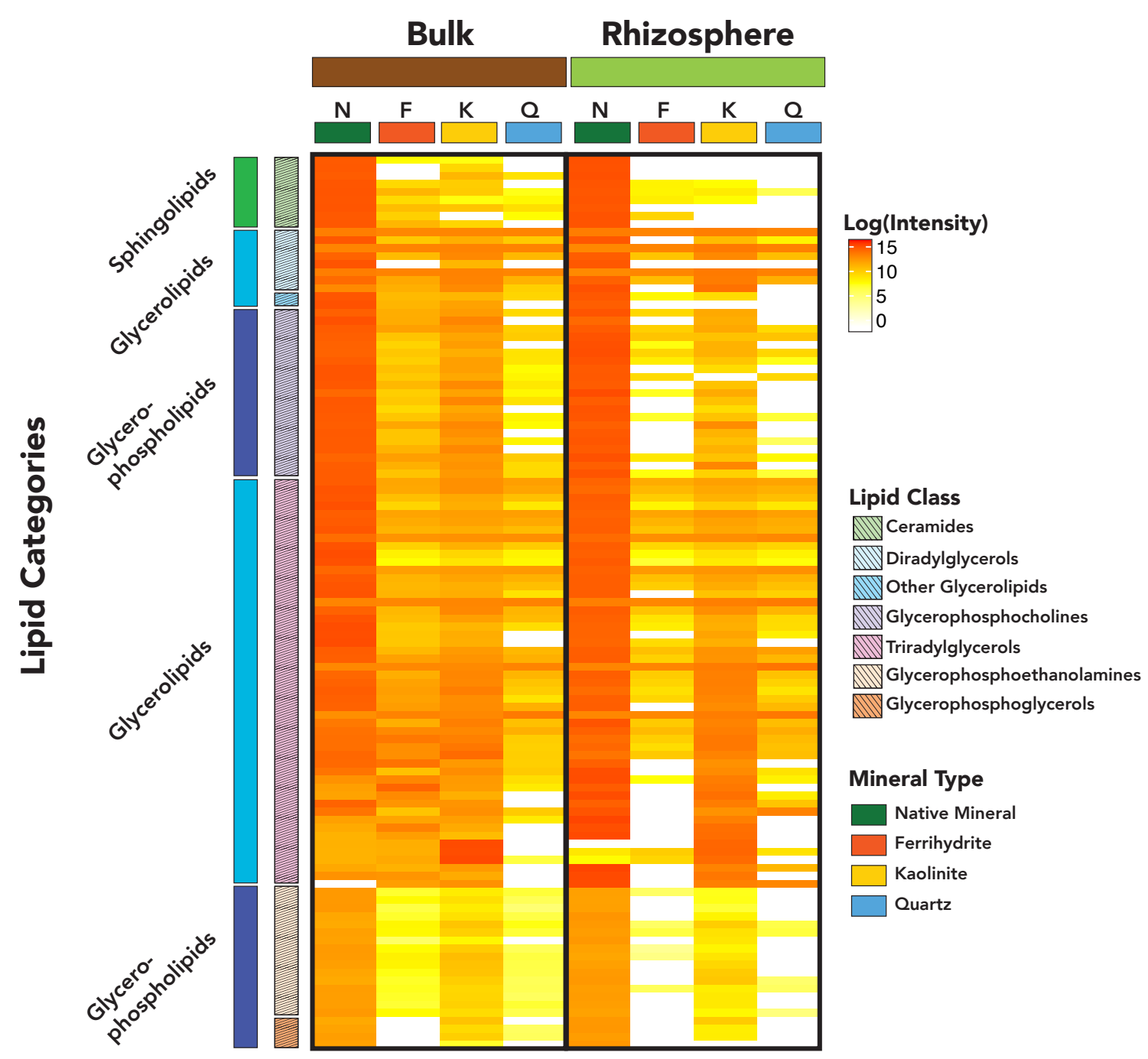

Figure 4. A heatmap comparison of $\log _{10}$ transformed lipid intensities for lipids identified in lipidomic analysis across treatment (bulk and rhizosphere) and mineral type (Native Mineral, Ferrihydrite, Kaolinite, and Quartz) (n=3). Due to differences in ionization potential, comparisons should only be made within lipid sub-class, rather than across broad lipid categories. 


\subsection{Microbial signatures in mineral-associated SOM chemistry}

The largest class of lipids observed across mineral type and treatment was triacylglycerolipids (TG), with 59 total unique lipids. These storage lipids, which are highly abundant in fungi ${ }^{82}$, are also found in plants and the bacterial genus Actinomyces 83. When we analyzed microbial colonization of the minerals from our study (published separately ${ }^{84}$ ), Actinobacteria was the second most abundant phylum associated with the incubated minerals. The distribution of unique lipids within the TG class by mineral type was highly significantly different $(\mathrm{p}<0.001)$. Comparing lipid intensities, for many of the TG, Kaolinite had almost as high a lipid intensity as the Native Minerals, and for a few of the TGs, a higher intensity (Figure 4). Ferrihydrite also had high TG intensities in the bulk soil treatment. Thus, storage lipids may be an important component of mineral SOM.

We observed a diverse number of glycerophospholipids (GP), primarily of the classes diacylglycerophosphocholines (PC) and diacylglycerophophoethanolamines (PE). Highly abundant in bacteria ${ }^{85}$, these phospholipids are commonly structural components of cell membranes $^{86}$. Many of the GP lipids we observed had odd numbers of $\mathrm{C}$ atoms $(15,17$, or $19 \mathrm{C}$ long fatty acids). Based on the structure of the Glycerophospholipids we identified, we believe that many were bacterial membrane lipids ${ }^{87}$.

Only 9 sphingolipids were observed, all of them in the ceramides and dihydroceramides sub-class. Ceramides are typically found in plants ${ }^{82}$, but are also present in most fungi and in a few anaerobic bacteria, such as Bacteroides $\mathrm{spp}^{82,85}$, which are from one of the 
top ten bacterial phyla associated with the specimen minerals ${ }^{84}$. Interestingly, we observed more unique sphingolipids in the minerals from the bulk soil treatment than the rhizosphere treatment, which indicates that these lipids are more likely microbial than plant-derived (Figure 4).

Prior work on in our experimental system showed that mineral type shaped microbial association and assembly on mineral surfaces ${ }^{84}$. The distinct lipid signature we observed different mineral types may have been driven in part by the phylogenetically distinct microbial communities on these minerals. Chemical sorption may also play a role in determining which lipids end up on - or come off of - which mineral types. The microbial signature of mineral-associated lipids suggests that, if we know the soil mineral type, studying the microbial community composition and functional capacity may help in predictive modeling of mineral-associated SOM. Future research efforts examining the role of microbial ecophysiology on the fate of SOM may provide insights into the mechanisms through which soil microbes drive SOM persistence.

\subsection{Towards predicting mineral-associated SOM persistence}

Comparing the specimen minerals to Native Minerals allows for prediction of $\mathrm{OM}$ association over time. If we were to assume $\mathrm{OM}$ accumulates at a constant linear rate, in approximately 40 years, an average specimen mineral, initially free of detectable OM, would be coated in as much OM as the Native Minerals. However, we predict it would take far longer for a specimen mineral with no OM to accumulate the $\sim 16 \mathrm{mg} \mathrm{C}$ per $\mathrm{g}$ mineral we observed on Native Minerals because accumulation is not likely a linear, 
constant process ${ }^{74-75}$. In our results, we appear to be observing signals of a system in flux, as proposed in Eq. 2.

In the rhizosphere, an actively growing plant releases a diverse array of carbon substrates ${ }^{50,88}$. Our ${ }^{13} \mathrm{C}-\mathrm{NMR}$ results suggest that the rhizosphere leaves a distinct chemical fingerprint on mineral-associated OM. While some of these rhizosphere compounds may be sorbed directly from the root, we expect a large fraction of the mineral-associated OM is microbially derived. Indeed, the location of peaks in the rhizosphere mineral's ${ }^{13} \mathrm{C}$ NMR spectra resemble those of $E$. coli cells, as analyzed by Wang et al. ${ }^{89}$. Our prior work ${ }^{84}$ reveals a diverse mineralosphere microbial community. Rhizosphere compounds could also be altered by abiotic processes prior to sorption. However, despite likely transformation of a portion of the rhizosphere-derived compounds, the rhizosphere treatment maintains a unique chemical signature that distinguishes it from the bulk soil treatment.

We see evidence that the unique chemical fingerprint of the rhizosphere may not persist, particularly in the comparison of the Native Minerals to Kaolinite. Prior to being fieldcollected, the Native Minerals were undoubtedly periodically rhizosphere influenced. However, the chemistry of Native Minerals incubated in the bulk soil closely resembles that of the Kaolinite mineral that was incubated for only two months in bulk soil. The similarity between the broad ${ }^{13} \mathrm{C}-\mathrm{NMR}$ chemistry of the Native Minerals and Kaolinite minerals in the bulk soil treatment suggest that, over time, many mineral-associated 
carbonyls and carbohydrates are either desorbed from the mineral surface or transformed, leaving behind mostly lipids.

The hydrophobic nature of lipids may lead to associations with mineral surface complexes ${ }^{90}$ that are relatively difficult to desorb. In our system, lipids seemed to associate strongly with Kaolinite, which had the highest intensities of most lipid classes of the specimen minerals (Figure 4). Microbial assimilation of $\mathrm{C}$ compounds may result in transformation of those compounds to lipids as microbes synthesize membranes and storage lipids. We expect that over time, a larger portion of the mineral surface is occupied by microbial necromass, including microbial lipid residues.

While lipids may persist, sequential extractions indicate that a large portion of mineralassociated $\mathrm{C}$ was water extractable, and thus may readily exchange with the soil DOC pool. This fraction of extractable total $\mathrm{C}$ was strongly dependent on mineral type (SI Figure 10). Nearly all Quartz-associated $C$ was removed via the water extraction $(88 \%$ for rhizosphere, $100 \%$ for bulk soil), whereas a larger portion $\mathrm{C}$ remained on the Ferrihydrite and Kaolinite, highlighting the importance of stronger chemical associations between SOM and the mineral (e.g. ligand exchange) for C persistence (SI Figure 10 $)^{77}$. Interestingly, in the rhizosphere treatment, we saw that atom $\%{ }^{13} \mathrm{C}$ increased with each extraction for Kaolinite (SI Figure 10). This increase in atom $\%{ }^{13} \mathrm{C}$ of Kaoliniteassociated $\mathrm{C}$ following an extraction indicates preferential persistence of $A$. barbataderived $\mathrm{C}$ compounds. This suggests that chemistry of both the mineral surface and also the carbon substrate are important in controlling mineral-associated $\mathrm{C}$ persistence. 
Our results provide evidence that SOM turnover is faster in rhizosphere than bulk soil. We also observe the potential importance of mineral type for predicting total SOM association with minerals. Prior work shows that short range order minerals, such as ferrihydrite, often have the oldest associated carbon ${ }^{6,46-47,91}$. However, our study shows that mineral type influences on total $\mathrm{C}$ accumulation can be context-dependent (rhizosphere versus bulk soil). In the rhizosphere, Ferrihydrite had the highest total C, but in the bulk soil, Kaolinite had higher total C. Thus, mineral type alone may be insufficient to predict $\mathrm{C}$ accumulation and turnover. The presence or absence of root influence also appears to play a critical role in determining the chemistry and fate of mineral-associated $\mathrm{C}$.

Our study emphasizes the importance of understanding plant-microbe-mineral interactions in concert to understand the mechanisms of $\mathrm{C}$ transformation and persistence in soil. We found critical differences between bulk soil and rhizosphere soils, which are likely particularly important in a seasonal system such as our model annual grassland ecosystem growing in a Mediterranean-type climate. While further work is needed to examine these systems over longer time scales, the results of this study provide a snapshot of $\mathrm{C}$ flow from plants to minerals over the course of a season as $A$. barbata grows and senesces. Carbon association with minerals is dynamic, particularly so in the rhizosphere. Based on our findings, we suggest that increasing $\mathrm{C}$ supply does not necessarily result in increased $\mathrm{C}$ association with minerals over a short timescale. Instead, 
differences in $\mathrm{C}$ source and environment impact mineral-associated $\mathrm{C}$ composition, which in turn could influence longer-term persistence.

\section{Acknowledgements:}

This research was supported by the US Department of Energy (DOE) Office of Science, Office of Biological and Environmental Research Genomic Science program under award DE-SC0016247 (to MKF) and awards SCW1589, SCW1421 and the LLNL Soil Microbiome SFA, SCW1632 (to JPR). RAN was supported by a Livermore Scholar Program fellowship at Lawrence Livermore National Laboratory and a National Science Foundation Doctoral Dissertation Improvement Grant, award 1601809. Part of this work was conducted at the Environmental Molecular Sciences Laboratory (grid.436923.9), a DOE Office of Science scientific user facility sponsored by the Department of Energy's Office of Biological and Environmental Research and located at PNNL under contract DE-AC05-76RL01830. Work conducted at Lawrence Livermore National Laboratory was supported under the auspices of the U.S. DOE under Contract DE-AC52-

07NA27344. Work conducted at Lawrence Berkeley National Laboratory was supported under Contract DE-AC02-05CH11231. Soil and plant collection were supported by the Hopland Research and Extension Center. Plants were grown and labeled at the University of California, Berkeley, Oxford Tract Greenhouse Facility. Sampling efforts and technical expertise were provided by Rina Estera-Molina.

Garrison Sposito provided invaluable insight and advice on the experimental design and interpretations. 


\section{References:}

1. Paul, E. A., The nature and dynamics of soil organic matter: Plant inputs, microbial transformations, and organic matter stabilization. Soil Biology and Biochemistry 2016, 98, 109-126.

2. Sokol, N. W.; Kuebbing, S. E.; Karlsen-Ayala, E.; Bradford, M. A., Evidence for the primacy of living root inputs, not root or shoot litter, in forming soil organic carbon. New Phytologist 2019, 221 (1), 233-246.

3. Finzi, A. C.; Abramoff, R. Z.; Spiller, K. S.; Brzostek, E. R.; Darby, B. A.; Kramer, M. A.; Phillips, R. P., Rhizosphere processes are quantitatively important components of terrestrial carbon and nutrient cycles. Global Change Biology 2015, 21 (5), 2082-2094.

4. Kuzyakov, Y.; Domanski, G., Carbon input by plants into the soil. Review. Journal of Plant Nutrition and Soil Science 2000, 163 (4), 421-431.

5. Rasse, D. P.; Rumpel, C.; Dignac, M. F., Is soil carbon mostly root carbon?

Mechanisms for a specific stabilisation. Plant and Soil 2005, 269 (1-2), 341-356.

6. Torn, M. S.; Trumbore, S. E.; Chadwick, O. A.; Vitousek, P. M.; Hendricks, D. M., Mineral control of soil organic carbon storage and turnover. Nature 1997, 389 (6647), 170-173.

7. Schmidt, M. W. I.; Torn, M. S.; Abiven, S.; Dittmar, T.; Guggenberger, G.; Janssens, I. A.; Kleber, M.; Kogel-Knabner, I.; Lehmann, J.; Manning, D. A. C.; Nannipieri, P.; Rasse, D. P.; Weiner, S.; Trumbore, S. E., Persistence of soil organic matter as an ecosystem property. Nature 2011, 478 (7367), 49-56.

8. Kleber, M.; Eusterhues, K.; Keiluweit, M.; Mikutta, C.; Mikutta, R.; Nico, P. S., Mineral-Organic Associations: Formation, Properties, and Relevance in Soil Environments. In Advances in Agronomy, Vol 130, Sparks, D. L., Ed. 2015; Vol. 130, pp $1-140$.

9. Kogel-Knabner, I.; Guggenberger, G.; Kleber, M.; Kandeler, E.; Kalbitz, K.; Scheu, S.; Eusterhues, K.; Leinweber, P., Organo-mineral associations in temperate soils:

Integrating biology, mineralogy, and organic matter chemistry. Journal of Plant Nutrition and Soil Science 2008, 171 (1), 61-82.

10. Trumbore, S., Age of soil organic matter and soil respiration: radiocarbon constraints on belowground c dynamics. Ecological Applications 2000, 10 (2), 399-411.

11. Hemingway, J. D.; Rothman, D. H.; Grant, K. E.; Rosengard, S. Z.; Eglinton, T. I.; Derry, L. A.; Galy, V. V., Mineral protection regulates long-term global preservation of natural organic carbon. Nature 2019, 570 (7760), 228-231. 
12. Heckman, K.; Throckmorton, H.; Horwath, W. R.; Swanston, C. W.; Rasmussen, C., Variation in the Molecular Structure and Radiocarbon Abundance of Mineral-Associated Organic Matter across a Lithosequence of Forest Soils. Soil Systems 2018, 2 (2).

13. Bailey, V. L.; Pries, C. H.; Lajtha, K., What do we know about soil carbon destabilization? Environmental Research Letters 2019, 14 (8).

14. Lehmann, J.; Hansel, C. M.; Kaiser, C.; Kleber, M.; Maher, K.; Manzoni, S.; Nunan, N.; Reichstein, M.; Schimel, J. P.; Torn, M. S.; Wieder, W. R.; Kögel-Knabner, I., Persistence of soil organic carbon caused by functional complexity. Nature Geoscience 2020, 13 (8), 529-534.

15. Stockmann, U.; Adams, M. A.; Crawford, J. W.; Field, D. J.; Henakaarchchi, N.; Jenkins, M.; Minasny, B.; McBratney, A. B.; de Courcelles, V. D.; Singh, K.; Wheeler, I.; Abbott, L.; Angers, D. A.; Baldock, J.; Bird, M.; Brookes, P. C.; Chenu, C.; Jastrow, J. D.; Lal, R.; Lehmann, J.; O'Donnell, A. G.; Parton, W. J.; Whitehead, D.; Zimmermann, M., The knowns, known unknowns and unknowns of sequestration of soil organic carbon. Agriculture Ecosystems \& Environment 2013, 164, 80-99.

16. Lal, R., Soil carbon sequestration impacts on global climate change and food security. Science 2004, 304 (5677), 1623-1627.

17. Lal, R., Soil carbon sequestration to mitigate climate change. Geoderma 2004, 123 (1-2), 1-22.

18. Tang, J. Y.; Riley, W. J., Weaker soil carbon-climate feedbacks resulting from microbial and abiotic interactions. Nature Climate Change 2015, 5 (1), 56-60.

19. Schimel, J. P.; Schaeffer, S. M., Microbial control over carbon cycling in soil. Frontiers in Microbiology 2012, 3.

20. Gregory, P. J., Roots, rhizosphere and soil: the route to a better understanding of soil science? European Journal of Soil Science 2006, 57 (1), 2-12.

21. Cotrufo, M. F.; Wallenstein, M. D.; Boot, C. M.; Denef, K.; Paul, E., The Microbial Efficiency-Matrix Stabilization (MEMS) framework integrates plant litter decomposition with soil organic matter stabilization: do labile plant inputs form stable soil organic matter? Global Change Biology 2013, 19 (4), 988-995.

22. Dwivedi, D.; Riley, W. J.; Torn, M. S.; Spycher, N.; Maggi, F.; Tang, J. Y., Mineral properties, microbes, transport, and plant-input profiles control vertical distribution and age of soil carbon stocks. Soil Biology \& Biochemistry 2017, 107, 244-259.

23. Pett-Ridge, J.; Shi, J.; Estera-Molina, K.; Nuccio, E. E.; Yuan, M.; Rijkers, R.; Swenson, T.; Zhalnina, K.; Northen, T. R.; Zhou, J.; Firestone, M. K., Rhizosphere carbon turnover from cradle to grave: the role of microbe-plant interactions. In 
Rhizosphere Biology: Interactions with Plants, Gupta, V.; Sharma, A. K., Eds. Springer Nature Press: 2021.

24. Kleber, M., What is recalcitrant soil organic matter? Environmental Chemistry 2010, 7 (4), 320-332.

25. Dungait, J. A. J.; Hopkins, D. W.; Gregory, A. S.; Whitmore, A. P., Soil organic matter turnover is governed by accessibility not recalcitrance. Global Change Biology 2012, 18 (6), 1781-1796.

26. Creamer, C. A.; Foster, A. L.; Lawrence, C.; McFarland, J.; Schulz, M.; Waldrop, M. P., Mineralogy dictates the initial mechanism of microbial necromass association.

Geochimica et Cosmochimica Acta 2019, 260, 161-176.

27. Roose, T.; Fowler, A. C., A mathematical model for water and nutrient uptake by plant root systems. Journal of Theoretical Biology 2004, 228 (2), 173-184.

28. Roose, T.; Schnepf, A., Mathematical models of plant-soil interaction. Philosophical Transactions of the Royal Society a-Mathematical Physical and Engineering Sciences 2008, 366 (1885), 4597-4611.

29. Keiluweit, M.; Bougoure, J. J.; Nico, P. S.; Pett-Ridge, J.; Weber, P. K.; Kleber, M., Mineral protection of soil carbon counteracted by root exudates. Nat Clim Change 2015, $5(6), 588-595$.

30. Hinsinger, P.; Bengough, A. G.; Vetterlein, D.; Young, I. M., Rhizosphere: biophysics, biogeochemistry and ecological relevance. Plant and Soil 2009, 321 (1-2), 117-152.

31. Philippot, L.; Raaijmakers, J. M.; Lemanceau, P.; van der Putten, W. H., Going back to the roots: the microbial ecology of the rhizosphere. Nature Reviews Microbiology

2013, 11 (11), 789-799.

32. Shi, S.; Richardson, A. E.; O'Callaghan, M.; DeAngelis, K. M.; Jones, E. E.; Stewart, A.; Firestone, M. K.; Condron, L. M., Effects of selected root exudate components on soil bacterial communities. Fems Microbiology Ecology 2011, 77 (3), 600-610.

33. Shi, S. J.; Nuccio, E.; Herman, D. J.; Rijkers, R.; Estera, K.; Li, J. B.; da Rocha, U. N.; He, Z. L.; Pett-Ridge, J.; Brodie, E. L.; Zhou, J. Z.; Firestone, M., Successional Trajectories of Rhizosphere Bacterial Communities over Consecutive Seasons. Mbio 2015, 6 (4).

34. Hutchens, E.; Gleeson, D.; McDermott, F.; Miranda-CasoLuengo, R.; Clipson, N., Meter-Scale Diversity of Microbial Communities on a Weathered Pegmatite Granite Outcrop in the Wicklow Mountains, Ireland; Evidence for Mineral Induced Selection? Geomicrobiology Journal 2010, 27 (1), 1-14. 
35. Uroz, S.; Calvaruso, C.; Turpault, M.-P.; Frey-Klett, P., Mineral weathering by bacteria: ecology, actors and mechanisms. Trends in Microbiology 2009, 17 (8), 378-387.

36. Uroz, S.; Kelly, L. C.; Turpault, M.-P.; Lepleux, C.; Frey-Klett, P., The Mineralosphere Concept: Mineralogical Control of the Distribution and Function of Mineral-associatec Bacterial Communities. Trends in Microbiology 2015, 23 (12), 751762.

37. Ehrlich, H. L., How microbes influence mineral growth and dissolution. Chemical Geology 1996, 132 (1-4), 5-9.

38. Banfield, J. F.; Barker, W. W.; Welch, S. A.; Taunton, A., Biological impact on mineral dissolution: Application of the lichen model to understanding mineral weathering in the rhizosphere. Proceedings of the National Academy of Sciences 1999, 96 (7), 3404.

39. Banfield, J.F.; Hamers, R.J., Chapter 3. Processes at minerals and surfaces with relevance to microorganisms and prebiotic synthesis. In GeomicrobiologyInteractions between Microbes and Minerals, 1997; Vol. 35.

40. Kleber, M.; Eusterhues, K.; Keiluweit, M.; Mikutta, C.; Mikutta, R.; Nico, P. S., Chapter One - Mineral-Organic Associations: Formation, Properties, and Relevance in Soil Environments. In Advances in Agronomy, Sparks, D. L., Ed. Academic Press: 2015; Vol. 130, pp 1-140.

41. Kallenbach, C. M.; Frey, S. D.; Grandy, A. S., Direct evidence for microbial-derived soil organic matter formation and its ecophysiological controls. Nature Communications 2016, 7 .

42. Sokol, N. W.; Sanderman, J.; Bradford, M. A., Pathways of mineral-associated soil organic matter formation: Integrating the role of plant carbon source, chemistry, and point of entry. Global Change Biology 2019, 25 (1), 12-24.

43. Liang, C.; Kästner, M.; Joergensen, R. G., Microbial necromass on the rise: The growing focus on its role in soil organic matter development. Soil Biology and Biochemistry 2020, 150, 108000.

44. Kaiser, M.; Ellerbrock, R. H.; Wulf, M.; Dultz, S.; Hierath, C.; Sommer, M., The influence of mineral characteristics on organic matter content, composition, and stability of topsoils under long-term arable and forest land use. Journal of Geophysical ResearchBiogeosciences 2012, 117.

45. Torn, M. S.; Kleber, M.; Zavaleta, E. S.; Zhu, B.; Field, C. B.; Trumbore, S. E., A dual isotope approach to isolate soil carbon pools of different turnover times.

Biogeosciences 2013, 10 (12), 8067-8081. 
46. Mikutta, R.; Kleber, M.; Torn, M. S.; Jahn, R., Stabilization of soil organic matter: Association with minerals or chemical recalcitrance? Biogeochemistry 2006, 77 (1), 25 56.

47. Kleber, M.; Mikutta, R.; Torn, M. S.; Jahn, R., Poorly crystalline mineral phases protect organic matter in acid subsoil horizons. European Journal of Soil Science 2005, $56(6), 717-725$.

48. Staley, C.; Ferrieri, A. P.; Tfaily, M. M.; Cui, Y.; Chu, R. K.; Wang, P.; Shaw, J. B.; Ansong, C. K.; Brewer, H.; Norbeck, A. D.; Markillie, M.; do Amaral, F.; Tuleski, T.; Pellizzaro, T.; Agtuca, B.; Ferrieri, R.; Tringe, S. G.; Paša-Tolić, L.; Stacey, G.;

Sadowsky, M. J., Diurnal cycling of rhizosphere bacterial communities is associated with shifts in carbon metabolism. Microbiome 2017, 5 (1), 65.

49. Kölling, K.; Thalmann, M.; Müller, A.; Jenny, C.; Zeeman, S. C., Carbon partitioning in Arabidopsis thaliana is a dynamic process controlled by the plants metabolic status and its circadian clock. Plant, Cell \& Environment 2015, 38 (10), 1965-1979.

50. Zhalnina, K.; Louie, K. B.; Hao, Z.; Mansoori, N.; da Rocha, U. N.; Shi, S. J.; Cho, H. J.; Karaoz, U.; Loque, D.; Bowen, B. P.; Firestone, M. K.; Northen, T. R.; Brodie, E. L., Dynamic root exudate chemistry and microbial substrate preferences drive patterns in rhizosphere microbial community assembly. Nature Microbiology 2018, 3 (4), 470-480.

51. Sudderth, E. A.; St Clair, S. B.; Placella, S. A.; Swarbreck, S. M.; Castanha, C.; Herman, D. J.; Fischer, M. L.; Kleber, M.; Sudderth, E. B.; Torn, M. S.; Firestone, M. K.; Andersen, G. L.; Ackerly, D. D., Annual grassland resource pools and fluxes: sensitivity to precipitation and dry periods on two contrasting soils. Ecosphere 2012, 3 (8).

52. Shi, S. J.; Nuccio, E. E.; Shi, Z. J.; He, Z. L.; Zhou, J. Z.; Firestone, M. K., The interconnected rhizosphere: High network complexity dominates rhizosphere assemblages. Ecology Letters 2016, 19 (8), 926-936.

53. Starr, E. P.; Nuccio, E. E.; Pett-Ridge, J.; Banfield, J. F.; Firestone, M. K., Metatranscriptomic reconstruction reveals RNA viruses with the potential to shape carbon cycling in soil. Proceedings of the National Academy of Sciences of the United States of America 2019, 116 (51), 25900-25908.

54. Starr, E. P.; Shi, S. J.; Blazewicz, S. J.; Probst, A. J.; Herman, D. J.; Firestone, M. K.; Banfield, J. F., Stable isotope informed genome-resolved metagenomics reveals that Saccharibacteria utilize microbially-processed plant-derived carbon. Microbiome 2018, 6 .

55. Nuccio, E. E.; Anderson-Furgeson, J.; Estera, K. Y.; Pett-Ridge, J.; de Valpine, P.; Brodie, E. L.; Firestone, M. K., Climate and edaphic controllers influence rhizosphere community assembly for a wild annual grass. Ecology 2016, 97 (5), 1307-1318. 
56. Nuccio, E. E.; Starr, E.; Karaoz, U.; Brodie, E. L.; Zhou, J.; Tringe, S. G.; Malmstrom, R. R.; Woyke, T.; Banfield, J. F.; Firestone, M. K.; Pett-Ridge, J., Niche differentiation is spatially and temporally regulated in the rhizosphere. Isme j 2020, 14 (4), 999-1014.

57. Tfaily, M. M.; Wilson, R. M.; Brewer, H. M.; Chu, R. K.; Heyman, H. M.; Hoyt, D. W.; Kyle, J. E.; Purvine, S. O., Single-throughput Complementary High-resolution Analytical Techniques for Characterizing Complex Natural Organic Matter Mixtures. $J$. Vis. Exp. 2019, 143.

58. Tfaily, M. M.; Chu, R. K.; Toyoda, J.; Tolić, N.; Robinson, E. W.; Paša-Tolić, L.; Hess, N. J., Sequential extraction protocol for organic matter from soils and sediments using high resolution mass spectrometry. Anal Chim Acta 2017, 972, 54-61.

59. Tfaily, M. M.; Hess, N. J.; Koyama, A.; Evans, R. D., Elevated [CO2] changes soil organic matter composition and substrate diversity in an arid ecosystem. Geoderma 2018, $330,1-8$.

60. Tolić, N.; Liu, Y.; Liyu, A.; Shen, Y.; Tfaily, M. M.; Kujawinski, E. B.; Longnecker, K.; Kuo, L. J.; Robinson, E. W.; Paša-Tolić, L.; Hess, N. J., Formularity: Software for Automated Formula Assignment of Natural and Other Organic Matter from UltrahighResolution Mass Spectra. Anal Chem 2017, 89 (23), 12659-12665.

61. Kim, S.; Kramer, R. W.; Hatcher, P. G., Graphical Method for Analysis of UltrahighResolution Broadband Mass Spectra of Natural Organic Matter, the Van Krevelen Diagram. Analytical Chemistry 2003, 75 (20), 5336-5344.

62. Kyle, J. E.; Crowell, K. L.; Casey, C. P.; Fujimoto, G. M.; Kim, S.; Dautel, S. E.; Smith, R. D.; Payne, S. H.; Metz, T. O., LIQUID: an-open source software for identifying lipids in LC-MS/MS-based lipidomics data. Bioinformatics (Oxford, England) 2017, 33 (11), 1744-1746.

63. Pluskal, T.; Castillo, S.; Villar-Briones, A.; Oresic, M., MZmine 2: modular framework for processing, visualizing, and analyzing mass spectrometry-based molecular profile data. BMC Bioinformatics 2010, 11, 395-395.

64. Heckman, K.; Lawrence, C. R.; Harden, J. W., A sequential selective dissolution method to quantify storage and stability of organic carbon associated with $\mathrm{Al}$ and $\mathrm{Fe}$ hydroxide phases. Geoderma 2018, 312, 24-35.

65. Ross, G. L.; Wang, C., Extractable Al, Fe, Mn and Si. In Soil Sampling and Methods of Analysis, Carter, M. R., Ed. Lewis Publication: Boca Raton, 1993; pp 239-246.

66. Courchesne, F.; Turmel, M.-C., Extractable Al, Fe, Mn, and Si. In Soil Sampling and Methods of Analysis, Carter, M. R.; Gregorich, E. G., Eds. Canadian Society of Soil Science: Boca Raton, FL, 2008; Vol. 2, pp 307-316. 
67. Balesdent, J.; Mariotti, A.; Guillet, B., Natural 13C abundance as a tracer for studies of soil organic matter dynamics. Soil Biology and Biochemistry 1987, 19 (1), 25-30.

68. Doncaster, C. P.; Davey, A. J. H., Analysis of Variance and Covariance. [electronic resource] : How to Choose and Construct Models for the Life Sciences. Cambridge : Cambridge University Press, 2007: 2007.

69. Pinheiro, J.; Bates, D.; DebRoy, S.; Sarkar, D.; Team, R. C. nlme: Linear and Nonlinear Mixed Effects Models, R package version 3.1-139, 2019.

70. Lenth, R. emmeans: Estimate Marginal Means, aka Least-Squares Means, R package 2019.

71. Bramer, L.; White, A. fticRanalysis: Analysis and visualization tools for ICR data, version 0.4.; R package, 2018.

72. Oksanen, J.; Blanchet, F. G.; Friendly, M.; Kindt, R.; Legendre, P.; McGlinn, D.; Minchin, P. R.; O'Hara, R. B.; Simpson, G. L.; Solymos, P.; Stevens, M. H. H.; Szoecs, E.; Wagner, H. vegan: Community Ecology Package, version 2.5-4; R package, 2019.

73. Castellano, M. J.; Mueller, K. E.; Olk, D. C.; Sawyer, J. E.; Six, J., Integrating plant litter quality, soil organic matter stabilization, and the carbon saturation concept. Global Change Biology 2015, 21 (9), 3200-3209.

74. Six, J.; Conant, R. T.; Paul, E. A.; Paustian, K., Stabilization mechanisms of soil organic matter: Implications for C-saturation of soils. Plant and Soil 2002, 241 (2), 155176.

75. Stewart, C. E.; Paustian, K.; Conant, R. T.; Plante, A. F.; Six, J., Soil carbon saturation: concept, evidence and evaluation. Biogeochemistry 2007, 86 (1), 19-31.

76. Baisden, W. T.; Amundson, R.; Cook, A. C.; Brenner, D. L., Turnover and storage of $\mathrm{C}$ and $\mathrm{N}$ in five density fractions from California annual grassland surface soils. Global Biogeochemical Cycles 2002, 16 (4).

77. Sposito, G., The chemistry of soils. 2nd ed.; Oxford University Press: Oxford ; New York, 2008; p xii, 329 p.

78. Huo, C.; Luo, Y.; Cheng, W., Rhizosphere priming effect: A meta-analysis. Soil Biology and Biochemistry 2017, 111, 78-84.

79. Buckeridge, K. M.; La Rosa, A. F.; Mason, K. E.; Whitaker, J.; McNamara, N. P.; Grant, H. K.; Ostle, N. J., Sticky dead microbes: Rapid abiotic retention of microbial necromass in soil. Soil Biology and Biochemistry 2020, 149, 107929. 
80. Shi, S.; Nuccio, E.; Herman, D. J.; Rijkers, R.; Estera, K.; Li, J.; da Rocha, U. N.; He, Z.; Pett-Ridge, J.; Brodie, E. L.; Zhou, J.; Firestone, M., Successional Trajectories of Rhizosphere Bacterial Communities over Consecutive Seasons. Mbio 2015, 6 (4).

81. Cai, Y.; Tang, Z.; Xiong, G.; Xie, Z.; Liu, Z.; Feng, X., Different composition and distribution patterns of mineral-protected versus hydrolyzable lipids in shrubland soils. Journal of Geophysical Research: Biogeosciences 2017, 122 (9), 2206-2218.

82. Harwood, J. L.; Russell, N. J., Lipids in plants and microbes. G. Allen \& Unwin: London; Boston, 1984; p 162 p.

83. Alvarez, H. M.; Steinbuchel, A., Triacylglycerols in prokaryotic microorganisms. Applied Microbiology and Biotechnology 2002, 60 (4), 367-376.

84. Whitman, T.; Neurath, R.; Perera, A.; Ning, D.; Zhou, J. Z.; Nico, P.; Pett-Ridge, J.; Firestone, M., Microbial community assembly differs across mineral types in a rhizosphere microcosm. Environmental Microbiology 2018, 20, 4444-4460.

85. Sohlenkamp, C.; Geiger, O., Bacterial membrane lipids: diversity in structures and pathways. Fems Microbiology Reviews 2016, 40 (1), 133-159.

86. Siliakus, M. F.; van der Oost, J.; Kengen, S. W. M., Adaptations of archaeal and bacterial membranes to variations in temperature, $\mathrm{pH}$ and pressure. Extremophiles 2017, $21(4), 651-670$.

87. Ding, S.; Lange, M.; Lipp, J.; Schwab, V. F.; Chowdhury, S.; Pollierer, M. M.; Krause, K.; Li, D.; Kothe, E.; Scheu, S.; Welti, R.; Hinrichs, K.-U.; Gleixner, G., Characteristics and origin of intact polar lipids in soil organic matter. Soil Biology and Biochemistry 2020, 151, 108045.

88. Pett-Ridge, J.; Firestone, M. K., Using stable isotopes to explore root-microbemineral interactions in soil. Rhizosphere 2017, 3, 244-253.

89. Wang, Y.; Griffin, P.; Jin, K.; Fogel, M. L.; Steele, A.; Cody, G. D., Tracing H isotope effects in the dynamic metabolic network using multi-nuclear $(1 \mathrm{H}, 2 \mathrm{H}$ and $13 \mathrm{C})$ solid state NMR and GC-MS. Organic Geochemistry 2013, 57, 84-94.

90. Kleber, M.; Sollins, P.; Sutton, R., A conceptual model of organo-mineral interactions in soils: self-assembly of organic molecular fragments into zonal structures on mineral surfaces. Biogeochemistry 2007, 85 (1), 9-24.

91. Porras, R. C.; Hicks Pries, C. E.; Torn, M. S.; Nico, P. S., Synthetic iron (hydr)oxideglucose associations in subsurface soil: Effects on decomposability of mineral associated carbon. Science of The Total Environment 2018, 613-614, 342-351. 